\title{
First report of tomato spotted wilt virus in cucumber in Turkey
}

\author{
Serpil ERILMEZ ${ }^{1}$ (D)
}

Received: 8 February 2021 / Accepted: 8 February 2022 / Published online: 14 February 2022

(c) The Author(s) under exclusive licence to Società Italiana di Patologia Vegetale (S.I.Pa.V.) 2022

Keywords Cucumber $\cdot$ Tomato spotted wilt virus $\cdot$ RT-PCR

Tomato spotted wilt virus (TSWV), the type member of the genus Orthotospovirus (Tospoviridae), is one of the most widespread and economically important plant viruses affecting many crops such as tomato, pepper, potato, tobacco, peanut, lettuce, bean, and ornamental species. In June 2019, symptomatic cucumber (Cucumis sativus L.) plants were observed in a commercial cucumber greenhouse in İzmir (western Turkey). Plants exhibited symptoms of leaf mottling, mosaic, bronzing, narrow leaves and deformed fruits with chlorotic spots. Disease incidence was estimated as $30 \%$. Leaf samples collected from 8 symptomatic plants were analyzed for the presence of cucumber mosaic virus (CMV), TSWV, squash mosaic virus (SqMV) and watermelon mosaic virus (WMV) by commercial double-antibody sandwich (DAS)-ELISA kits (Bioreba AG, Reinach, Switzerland). All symptomatic plants were TSWV-positive, and showed no reaction with the antisera to CMV, SqMV, and WMV. The presence of TSWV was confirmed by RT-PCR using as template total RNA extracted by a silica capture method from fresh, symptomatic cucumber leaves (Foissac et al. 2001) and specific primers designed to amplify a fragment of the RdRP gene (TSWV-F: AATTGCCTTGCAACC AATTC and TSWV-R: ATCAGTCGAAAT GGTCGGCA; Mumford et al. 1994). A PCR product of the expected size
(276 bp) was obtained from plants that were TSWV positive in ELISA. PCR products of three randomly selected positive samples were directly sequenced (OK469363, OK469364, OK469365) and BLAST analysis of the obtained sequences revealed $>99 \%$ nucleotide identity to multiple TSWV isolates, with highest identity to a tomato isolate from France (MK792774). To our knowledge, this is the first report of this pathogen in cucumber plants in Turkey.

\section{References}

Foissac X, Svanella-Dumas L, Gentit P, Dulucq MJ, Candresse T (2001) Polyvalent detection of fruit tree Tricho, Capillo and Foveaviruses by nested RT-PCR using degenerated and inosinecontaining primers (PDO RT-PCR). Acta Hort 550:37-44

Mumford RA, Barker I, Wood KR (1994) The Detection of Tomato Spotted Wilt Virus Using The Polymerase Chain Reaction. J Virol Methods 46:303-311

Publisher's Note Springer Nature remains neutral with regard to jurisdictional claims in published maps and institutional affiliations.
Serpil ERILMEZ

serpilerilmez@gmail.com

1 Bornova Plant Protection Research Institute, 35040 Izmir, Turkey 